УДК 373.3.016:159.942

DOI: 10.37026/2520-6427-2021-108-4-119-123
Вячеслав ДЕМЧЕНКО,

кандидат педагогічних наук, доиент, доиент кафедри педагогіки, психології та корекційної освіти Рівненського обласного інституту післядипломної педагогічної освіти, м. Рівне, Україна

ORCID: 0000-0002-6792-3913

e-mail:demchenko1052@ukr.net

\title{
ЕМОЦЙНИЙ ІНТЕЛЕКТ ЯК ЗАСІБ ПІДВИЩЕННЯ КОГНІТИВНИХ ТА КРЕАТИВНИХ МОЖЛИВОСТЕЙ МОЛОДШИХ ШКОЛЯРІВ
}

\begin{abstract}
Анотація. У статті зроблено спробу проаналізувати можливість впливу емоційного інтелекту на розвиток когнітивних та креативних можливостей сучасних школярів початкової школи, адже ия проблема є неабияк актуальною в прочесі реалізачії Концепиії Нової украӥнської школи з притаманною ій гуманізацією системи освіти. Наведено деякі гіпотези i припущення стосовно того, щуо розвинена емоційна сфера дитини сприятливо впливає на розвиток ї̈ природного потенціалу. Продемонстровано прямий зв'язок між віком дитини та ефективністю розвитку їі емоиійної сфери. Доведено, щя емоиійний інтелект необхідно розвивати з раннього дитинства, адже люди
\end{abstract}

з високим рівнем емоиійного інтелекту не лише добре розуміють власні емочії та почуття й ефективно керують своєю емочійною сферою, а й завдяки ицьому їхня поведінка в суспільстві більш адаптивна, вони легше досягають свойх иілей у взаємодї з оточуючими. Виокремлено чотири складові емоційного інтелекту, а саме: сприйняття емоцій; використання емоцій для стимуляиії мислення; розуміння емоцій; управління емоціями. Наведено приклади ігор, щзо спрямовані на розуміння молодиими школярами своїх почуттів, мотивів та реакиій

Ключові слова: емоцій, емоційний інтелект, когнітивність, креативність, здібності.

\author{
Viacheslav DEMCHENKO, \\ Candidate of Philosophical Sciences, \\ Associate Professor, \\ Department of Pedagogy, \\ Psychology and Correctional Education, \\ Rivne Regional Institute \\ of Postgraduate Pedagogical Education, \\ Rivne, Ukraine \\ ORCID: 0000-0002-6792-3913 \\ e-mail:demchenko1052@ukr.net
}

\section{EMOTIONAL INTELLIGENCE AS INSTRUMENT OF INCREASING COGNITIVE AND CREATIVE CAPABILITIES OF JUNIOR SCHOOL CHILDREN}

\begin{abstract}
The article deals with the purpose of analysis possibility of impact of emotional intelligence on the development of cognitive and creative abilities of students and junior school children. It has been noted that people with a high level of emotional intelligence have a clear understanding of their emotions and feelings of other people and ability of effective control of their emotional sphere.

As a result, their behavior in society is more adaptive and they can easily achieve goals in interaction with others. Therefore, there is a necessity to develop emotional intelligence from early childhood, especially when the child is «covered» by the system of education.

Some of researches depicts the direct interaction between a child's age and the efficiency of development of their emotional sphere. The actuality of this issue became
\end{abstract}

especially relevant and important in the process of implementing the concept of the New Ukrainian School with its humanization of the education system.

In domestic psychology, the necessity for the term "emotional intelligence» was conditioned to the development of research in field of emotions and intelligence, the studies of the interactions between the mental and affective in the structure of mental activity and the study of emotional abilities. Modern psychological theory and practice have a widely learning doctrine for features of the individual emotional sphere, such as: empathy, vulnerability, emotionality and emotional stability.

It has not been conducted in our country and abroad thorough, systematic and effective studies of the impact of emotional intelligence on the development of cognitive 
and creative abilities of children. There are hypotheses and assumptions that the developed emotional sphere of the child has a positive effect on the development of its natural potential. However, some authors criticize this concept in connection with the vagueness and excessive breadth of the very concept of emotional intelligence. Overly optimistic predictions about the crucial importance of emotional intelligence compared to IQ and lack of empirical research that could confirm (or refute) numerous theoretical materials.

Key words: emotion, emotional, intelligence, cognitiveness, creativity, capabilities.

Постановка проблеми. Емоційний інтелект - це група ментальних здібностей, які беруть участь в усвідомленні та розумінні як власних емоцій людини, так і емоцій оточуючих, тобто це певна людська здатність до дуже точного відчуття ситуації, розуміння бажань оточуючих, стійкості до стресу і впливу негативних емоцій. Люди з високим рівнем такого інтелекту добре розуміють почуття та ефективно керують своєю емоційною сферою. Саме тому під час взаємодії із суспільством поведінка таких людей більш адаптивна, вони вміють успішно діяти за будь-яких обставин, а також легко знаходять компроміси в складних ситуаціях. Як результат - комунікація з навколишнім світом вибудовується легше та краще, а цілі досягаються ефективніше й швидше (Шамонова, 2021).

Загальний інтерес до емоційного інтелекту виник понад 25 років тому, коли психолог Деніель Гоулман випустив книгу, в якій розповів про його важливість. Сьогодні ідея вченого не втрачають своєї актуальності (Гоулман, 2018), а чимало його послідовників підтверджують, що емоційний інтелект відіграє в успішності та загальному благополуччі людини більшу роль, аніж IQ. Отже, розвивати емоційний інтелект краще і легше саме в дитинстві.

Аналіз наукових досліджень і публікацій. У психології та професійній підготовці психолога / педагога поняття і теорія емоційного інтелекту (здібності), емоційної компетентності як важливої умови успішності особистості застосовується відносно недавно - iз 1990 p., про що свідчать дослідження зарубіжних учених (П. Селовей і Дж. Майєр, Д. Гоулман, Р. Бар-Он). Вони трактували емоційний інтелект як підструктуру соціального інтелекту, яка включає «здатність відстежувати власні та чужі почуття й емоції, розрізняти їх і використовувати цю інформацію для направлення мислення і дій». Особлива увага розвитку і застосуванню емоційного інтелекту приділяється в менеджменті (Д. Гоулман, Р. Бояцис, Е. Маккі, М. Кетс де Вріс, Р. К. Купер та ін.).

Ця концепція має не лише своїх прихильників, а й противників. Зокрема, іiї критикують за розмитість i надмірну широту самого поняття емоційного інтелекту; зайві оптимістичні прогнози стосовно вирішального значення емоційного інтелекту в порівнянні з IQ; відсутність емпіричних досліджень, які могли б підтвердити (або спростувати) численний теоретичний матеріал; невиправдано завищені очікуваннями щодо впливу емоційного інтелекту на успіх у професійній діяльності (Р. Д. Робертс, Дж. Меттьюс, М. Зайднер, Д. В. Люсін та ін.).
В Україні проблемою емоційного інтелекту займалися вчені І. Ф. Аршава, О. І. Власова, С. П. Дерев'янко, Н. В. Коврига, Е. Л. Носенко. Вони виділяли такі функції емоційного інтелекту, як стресозахисна, адаптивна, рефлексивна, регулятивна.

Мета статті - окреслити вплив емоційного інтелекту на розвиток когнітивних та креативних можливостей молодших школярів.

Виклад основного матеріалу дослідження. Характер, зміст, глибина і складність проблем, перед якими опинилося сучасне суспільство, вимагають формування у здобувачів освіти нового типу мислення. В. Кремень у зв'язку з цим зауважував: «Який би конкретний шлях не обрала країна для подолання свого відставання, їй потрібно підвищити рівень і якість своїх людських ресурсів, тобто людина та ії мислення повинні бути інноваційними» (Кремень, 2008, с. 42).

У Концепції «Нова українська школа» (2016) визначено 10 ключових компетенцій сучасного випускника, серед яких особливу роль відведено вмінню мислити креативно. Відповідно у Державному стандарті базової середньої освіти (2020) зазначається, що «сучасний випускник школи повинен бути здатним до вибору серед численних альтернатив, що пропонує сучасне життя».

Безперечно, значну роль у самореалізації людини відіграє рівень IQ, адже саме $з$ його допомогою ми можемо вступити до бажаного університету або отримати довгоочікувану роботу, але не менш важливу роль у нашому становленні відіграє й розвинений емоційний інтелект. Кожна людина народжується 3 обов'язковим потенціалом емоційної сенситивності, емоційної пам'яті, емоційної обробки та емоційного научіння. Ці чотири вроджені компоненти формують основу емоційного інтелекту. Людина може розпочати життя з високим рівнем емоційного інтелекту, але 3 часом він може знизитися, якщо особистість набуває згубних емоційних звичок у сім'ї, де ії ображають та зневажають (Березюк, 2002, с. 20-23).

Згадані нами вище П. Селовей і Дж. Майєр акцентували увагу на когнітивних складових емоційного інтелекту як основі мислення та прийняття рішень. Зважаючи на це, виокремлюють чотири складові емоиійного інтелекту:

1) сприйняття емоцій - здатність розпізнавати емоції інших людей, а також ідентифікувати власні емоції;

2) використання емоцій для стимуляції мислення;

3) розуміння емоцій - уміння визначати причину появи емоції, перехід від однієї емоції до іншої, знаходження зв'язку між думками й емоціями;

4) управління емоціями (Андреева, 2009, с. 131).

Високий рівень емоційного інтелекту сприяє формуванню таких рис особистості, як самоповага, емоційна усвідомленість, самовираження, незалежність, емпатія, стресостійкість, гнучкість, оптимізм, щастя, соціальна відповідальність, допомагає налагодженню міжособистісних відносин, вирішенню проблем (Мошко, 2002, с. 345-346).

Особливої важливості розвиток EQ набуває в шкільному віці, оскільки у цей період відбувається активне емоційне відношення особистості до себе та до 
оточуючих. Навчальна діяльність сприяє вдосконаленню самосвідомості, здатності до рефлексії й децентралізації (вміння поставити себе на місце однокласника чи вчителя, врахувати їхні потреби та почуття).

Молодший шкільний вік - найкращий період для розвитку людської емоційної сфери, адже це період позитивних змін та перетворень, що відбуваються 3 особистістю. Якщо в цей період молодший школяр не відчуває почуття радості від пізнання, в нього не виникає впевненості у своїх здібностях і можливостях, то зробити це в подальшому буде надзвичайно важко, адже емоційний розвиток дитини є надто важливою складовою процесу розвитку особистості.

Розвиток емоційного інтелекту в молодшому шкільному віці необхідно розпочинати з основних емоцій, поступово переходячи на їхні відтінки. У цьому стануть в нагоді: читання книг 3 аналізом настрою $\mathrm{i}$ почуттів персонажів; різні види театрів; ігрові вправи «Вгадай настрій»; ситуації з життя учнів; демонстрація фотографій, малюнків осіб з основними емоціями та відтінками емоцій; малювання «власного настрою», а також настрою близьких, друзів; естетичне сприйняття світу тощо.

Дитина, навчаючись, не лише читає, пише та рахує, а й розмірковує, хвилюється, переживає, оцінює себе та своїх друзів. У зв'язку з цим основне завдання дорослих - допомогти їй зрозуміти саму себе і своє місце в колективі, власну значущість у взаємодії 3 учнями і вчителями, самоствердитися в собі та своїх можливостях, віднайти сили для подолання труднощів у навчанні. Лише тоді дитина зможе пізнавати не тільки зовнішній світ, а й себе в ньому. У цій гармонії шкільне навчання буде щасливим і радісним початком широкого та успішного життєвого шляху.

Ми, дорослі, повинні пам'ятати, що: емоційно значущі для дитини ситуації спонукають до самовираження; емоції створюють «платформу», на якій виписуються нові знання; емоційно забарвлені знання мотивують дитину до подальшого пізнання, вивчення, дослідження.

Керування емоціями як спосіб розвитку емоційного інтелекту полягає в стимулюванні фантазії та уяви дитини, використанні сюжетнорольових ігор як основного засобу розвитку EQ. Психологи стверджують, що в жодному разі не можна пропускати ігрову стадію розвитку дитини, адже у цей період формуються основи інтелекту дитини.

В освітньому процесі потрібно підтримувати певний емоційний баланс. Позитивне емоційне забарвлення - потужний мотиваційний фактор навчальної діяльності. Цю проблему можна вирішити за допомогою «очікуваної радості», якої має бути стільки, щоб горизонти дитячої свідомості завжди були переповнені зацікавленням. Навпаки, якщо дітям буде заборонено проявляти свої емоції, тобто педагог накладатиме на них табу, між учителем та учнем виникнуть серйозні проблеми у взаєморозумінні, адже емоції не лише $\epsilon$ «індикатором» стану дитини, а й істотно впливають на іiї пізнавальні процеси і поведінку, визначаючи спрямованість дитячої уваги, особливості сприйняття навколишнього світу, логіку суджень.

Молодші школярі потребують оцінки не стільки результату, скільки процесу навчання. Зусилля дитини, iii старання не повинні залишатися поза увагою вчителя. Педагогічна практика доводить, що ставлення до дітей як до талановитих особистостей неабияк допомагає їм у навчанні.

Щоб підвищити самооцінку учнів, учитель має:

- називати учня на ім'я, виявляючи таким чином шанобливе ставлення до нього;

- не критикувати зовнішність учня, його соціальне становище, не принижувати гідність, висловлюватися тільки з приводу його поведінки або вчинків;

- демонструвати однакові вимоги й однакове ставлення до всіх учнів у класі;

- відзначати позитивні досягнення, результати роботи кожного учня і звертати на це увагу всього класу;

- уникати порівнянь успіхів одного учня з успіхами інших;

- перетворювати невдачі учнів у позитивний навчальний і життєвий досвід;

- уникати надмірної опіки, цікавитися думкою учнів та поважати іiі, заохочувати у класі взаємодопомогу і взаємовиручку (Токарь, 2019).

Уже в початковій школі діти можуть ідентифікувати себе як особистість, яка не лише повинна поважати інших, а й сама заслуговувати на повагу оточуючих, незважаючи на відмінності, які існують між ними. У зв'язку 3 цим варто виокремити кілька складових емоційного інтелекту:

Периа складова - самопізнання, яке починається 3 правильного ставлення до самого себе. Адекватна самооцінка залежить від виховання та самоусвідомлення. Правильне виховання має закласти в дитині принцип самооцінки, за якого виходять із власних недоліків і досягнень, а не порівнюють себе з іншими людьми, оскільки в останньому випадку людина ніколи не зможе виробити об'єктивних критеріїв виміру своїх якостей.

Друга складова - емпатія, тобто розуміння відносин, почуттів, психічних станів іншої особи у формі співпереживання. Емпатію можна розглядати як афективну (емоційну) форму ідентифікації. Якщо при ідентифікації стан іншої людини визначається на основі раціональної інтерпретації, то при емпатії - на основі емоційного співпереживання. Розвиток емпатії у дітей залежить від того, як педагог сприятиме розвиткові стосунків між дітьми в колективі, як він сам виявляє емпатію до учнів, як він допомагає їм вирішувати конфлікти.

Третя складова - комунікабельність - одна з визначальних навичок успішної соціальної взаємодії, здатність людини до спілкування та встановлення соціальних зв'язків і контактів, до плідної взаємодії з іншими людьми, вміння знаходити компроміс у складних ситуаціях.

Є безліч шляхів розвитку емоційного інтелекту. Він також може розвиватися й «самостійно» - через живопис, мистецтво, літературу, гру, самоспостереження і ведення щоденників тощо. Однак, на нашу думку, найкращими практиками розвитку емоційного інтелекту є досвід і саме життя.

У школі та в родині зазвичай приділяють увагу розвитку традиційного, а не емоційного інтелекту. Емоції переважно розвиваються в дітей через наслідування. 
Так, якщо в родині діляться не тільки власними думками й досягненнями, а й неприємними моментами та проблемами, то ця частина емоційного інтелекту буде розвинена в більшості членів родини. Якщо ж у сім'ї заведено відчувати емоційний стан іншого, а не висловлювати власні емоції, ігноруючи партнера, то в дитини автоматично буде закладено здатність до емпатійності. А що ж робити, якщо приклади для наслідування в сім'ї відсутні? Тоді середовищем розвитку емоційного інтелекту має стати школа.

Сучасна психологія напрацювала величезну кількість вправ та методик, спрямованих на розуміння людиною своїх почуттів, мотивів та реакцій. Звичайно, найкращою формою емоційного розвитку дитини $\epsilon$ гра. Наведемо кілька прикладів таких ігор, які вчитель може запропонувати учням молодшої школи.

Гра «Емоційний крокодил». Дітям пропонується завдання: продемонструвати свої емоції, використовуючи міміку, тіло, голос, рухи.

Гра «Різнокольорова вода». Дітям пропонується розфарбувати воду в різні кольори, тобто зробили 1ii: «сердитою», «доброю», «веселою» тощо, а після цього з'ясувати, як за допомогою однієї й тієї ж фарби можна отримати різні відтінки, змінивши таким чином «настрій» води.

Гра «Інтерв'ю». Дітям пропонується розширити коло зрозумілих для них емоцій, розвинути здатність визначати емоції за графічними зображеннями; передати заданий емоційний стан за допомогою виразних рухів (міміки і пантоміми).

Гра «Малюємо емоції пальчиками». Дітям пропонується намалювати свої емоції, використовуючи не пензлик, а пальчики рук.

Гра «Чарівний мішечок». Учитель пропонує дітям скласти у «чарівний» мішечок усі негативні емоції: злість, образу, сум тощо, а потім цей мішечок знищити, позбавившись таким чином усього поганого (Токарь, 2019).

Отже, досвідчений педагог, аби розвинути емоційний інтелект своїх вихованців, їхні когнітивні та креативні здібності, не повинен зупинятися на досягнутому, постійно оволодівати і розширювати власний арсенал новими формами і методами.

Висновки. Розвиток емоційного інтелекту молодших школярів - тривалий і системний процес, що потребує спеціальної підготовки вчителів, планування ними виховного процесу з урахуванням визначених напрямів, завдань та особливостей, моделювання психологічно комфортного і безпечного освітнього середовища, напрацювання власних методик розвитку емоційного інтелекту, які б відображали, зокрема, й особливості та традиції українського національного менталітету та відповідали специфіці української освіти та педагогіки. Відповідно українські вчені-педагоги та педагоги-практики повинні більш комплексно і масштабно впроваджувати ефективні методи формування емоційного інтелекту як засобу успішного розвитку когнітивних та креативних можливостей здобувачів освіти в педагогічну практику.

Перспективи подальших досліджень стосуються вивчення впливу емоційного інтелекту на всебічний розвиток особистості, здатної вирішувати непрості проблеми сучасності та досягати успіху в житті.

\section{СПИСОК ВИКОРИСТАНОЇ ЛІТЕРАТУРИ}

Шамонова, О. (2021). Що таке емоційний інтелект та як він впливає на добробут людини. Украӥнська правда. 17 січня.

Гоулман, Д. (2018). Емоційний інтелект. Харків: Віват. С. 21.

Феномен Інновації: освіта, суспільство, культура: монографія. (2008) / за ред. В. Г. Кременя. Київ: Педагогічна думка. С. 42.

Концептуальні засади реформування середньої освіти «Нова українська школа». (2016). URL: https:// mon.gov.ua/storage/app/media/zagalna\%20serednya/ nova-ukrainska-shkola-compressed.pdf (дата звернення: 10.09.2021).

Державний стандарт базової середньої освіти: постанова Кабінету Міністрів України від 30.09.2020 р. № 898. URL: https://mon.gov.ua/ua/osvita/zagalna-serednyaosvita/nova-ukrayinska-shkola/derzhavnij-standart-bazovoyiserednoyi-osviti (дата звернення: 10.09.2021).

Березюк, Г. (2002). Емоційний інтелект як детермінанта внутрішньої свободи особистості. Психологічні студії Львівського університету. С. 20-23.

Андреева, И. Н. (2009). Концептуальное поле понятия «эмоциональный интеллект». Вопросы психологии. № 4. С. 131.

Мошко, И. И. (2018). Эмоциональный интеллект в работе инженера-программиста. Компьютерное проектирование и технология производства электронных систем: сборник тезисов. C. 345-346. URL: https:// libeldoc.bsuir.by/bitstream/123456789/32478/1/Moshko_ Emotsionalniy.pdf (дата обращения: 03.09.2021).

Токарь, Л. В. (2019). Емоційний інтелект як передумова розвитку успішної особистості. URL: http://kochubeevska-gromada.com.ua/data/documents/ DOSVID-TOKAR-L.V.pdf

\section{REFERENCES}

Shamonova, O. (2021). Shcho take emotsiinyi intelekt ta yak vin vplyvaie na dobrobut liudyny [What is emotional intelligence and how it affects human health]. Ukrainska pravda. 17 sichnia. [in Ukrainian].

Houlman, D. (2018). Emotsiinyi intelekt [Emotional intelligence]. Kharkiv: Vivat. S. 21. [in Ukrainian].

Fenomen innovatsii: osvita, suspilstvo, kultura [The phenomenon of Innovation: education, society, culture]: monohrafiia. (2008) / za red. V. H. Kremenia. Kyiv: Pedahohichna dumka. S. 42. [in Ukrainian].

Kontseptualni zasady reformuvannia serednoi osvity «Nova ukrainska shkola» [Conceptual principles of secondary education reform «New Ukrainian School»]. (2016). URL: https://mon.gov.ua/storage/app/media/zagalna\%20 serednya/nova-ukrainska-shkola-compressed.pdf (data zvernennia: 10.09.2021). [in Ukrainian].

Derzhavnyi standart bazovoi serednoi osvity [State standard of basic secondary education]: postanova Kabinetu Ministriv Ukrainy vid 30.09.2020 r. № 898. URL: https://mon.gov.ua/ua/osvita/zagalna-serednya-osvita/nova-ukrayinska-shkola/derzhavnij-standart-bazovoyi-serednoyi-osviti (data zvernennia: 10.09.2021). [in Ukrainian].

Bereziuk, H. (2002). Emotsiinyi intelekt yak determinanta vnutrishnoi svobody osobystosti [Emotional intelligence 
as a determinant of inner freedom of the individual]. Psykholohichni studii Lvivskoho universytetu. S. 20-23. [in Ukrainian].

Andreeva, I. N. (2009). Kontseptualnoe pole ponyatiya «emotsionalnyy intellekt» [Conceptual field of the concept of «emotional intelligence»]. Voprosy psikhologii. № 4. S. 131. [in Russian].

Moshko, I. I. (2018). Emotsionalnyy intellekt v rabote inzhenera-programmista [Emotional intelligence in the work of a software engineer]. Kompyuternoe proektirovanie i tekhnologiya proizvodstva elektronnykh sistem: sbornik tezisov. S. 345-346. URL: https://libeldoc.bsuir. by/bitstream/123456789/32478/1/Moshko_Emotsionalniy. pdf (data obrashcheniya: 03.09.2021). [in Russian].

Tokar, L. V. (2019). Emotsiinyi intelekt yak peredumova rozvytku uspishnoi osobystosti [Emotional intelligence as a prerequisite for the development of a successful personality]. URL: http://kochubeevska-gromada.com.ua/ data/documents/DOSVID-TOKAR-L.V.pdf (data zvernennia: 12.09.2021). [in Ukrainian].

Дата надходження до редакиії: 07.10.2021 p. 